Gut, 1985, 26, 325-331

Leading article

\title{
Spontaneous bacterial peritonitis
}

Infection of ascitic fluid without any apparent intra-abdominal foci of sepsis - spontaneous bacterial peritonitis (SBP) - is an often fatal complication of cirrhosis. Early publications emphasised the atypical features of such peritonitis and the frequency of misdiagnosis. ${ }^{1-4}$ The 16 year review by Conn ${ }^{4}$ in which the earlier prevalence of $8 \%$ in cirrhosis with ascites was reported to have risen to $18 \%$, lend credence to the view that there has been a true increase in SBP, quite apart from enhanced clinical awareness. The latter has resulted in the detection of a large number of patients with minimally symptomatic infections, which is well illustrated in one recent study ${ }^{6}$ embracing a five year period, which showed a 12-fold increase in the number of cases diagnosed with an atypical presentation of SBP compared with a four-fold rise in those with a more characteristic picture of peritonitis. Overall prevalence figures in more recently reported series approach $25 \% .^{78}$

This review addresses three questions: (1) What is the pathogenesis of this syndrome and can predisposing factors be identified? (2) When should it be suspected and what is the best means of diagnosis? (3) How can survival be improved?

\section{Pathogenesis and predisposing factors}

Infection with a single organism, usually enteric, is found in most cases. ${ }^{56}$ Gram negative bacilli are present in about $70 \%$ of isolates and are principally $E$ coli. ${ }^{579}$ Gram positive cocci, particularly pneumococcus, comprise an additional $10-20 \%$ of cases ${ }^{9-10}$ while anaerobes are found in $6-14 \% .^{11}$ The latter require special conditions of culture and are most often isolated when multiple organisms are grown. ${ }^{6}$

The frequent isolation of enteric organisms suggest that the gut is the most likely source of infection. Studies in patients with cirrhosis have shown colonisation of the upper small bowel with colonic flora. ${ }^{12}$ When portal hypertension is present permeability of the gut wall may be affected by oedema of the splanchnic tissues because of venous and lymphatic congestion. Organisms may be able to migrate across the gastrointestinal mucosa as the presence of hypertonic solutions in the peritoneal cavity of dogs results in the spread of $E$ coli from the gut. ${ }^{13} \mathrm{~A}$ similar explanation has been invoked to explain enteric bacterial peritonitis which sometimes occurs with peritoneal dialysis. If this was the mechanism, however, one would expect a larger proportion of ascitic infections to be due to anaerobes as they are a major constituent of the intestinal flora. ${ }^{14} \mathrm{~A}$ small number of patients with infections of the respiratory, or urinary tract also develop SBP with the same organism, ${ }^{67}$ which suggests that haematogenous spread occurs. Infection in the chest may also spread to the peritoneal cavity through transdiaphragmatic lymphatics. Bacteraemia caused by enteric organisms is a well recognised 
complication of patients with chronic liver disease. ${ }^{13}$ Indeed in at least $50 \%$ of patients the same organism is simultaneously isolated from blood and ascites, whilst in others blood cultures are positive when ascitic fluid is sterile. ${ }^{5}{ }^{15}$ Clinical and experimental data suggest that impaired function of the reticulo endothelial system (RE), in particular the Kupffer cells of the liver, together with intrahepatic and portasystemic shunting of blood, is important in the genesis of bacteraemia and SBP. ${ }^{16-19}$ Enteric bacteria normally removed by the hepatic RE system would then pass directly into the systemic circulation and could give rise to SBP. Against this hypothesis is the observation that several studies have failed to isolate organisms from the portal blood of cirrhotic patients. ${ }^{20-21}$ Whether peritonitis is a primary factor, or a consequence of bacteraemia is thus unclear.

Irrespective of the route of infection, the persistence of bacteraemia and spread of infection will be enhanced by defects of host defences, which are well recognised in patients with severe liver disease. Defects of serum bactericidal function, ${ }^{22}$ opsonisation, ${ }^{23}$ chemoattraction, ${ }^{24}{ }^{25}$ low serum concentrations of fibronectin ${ }^{26}$ and impaired function of polymorphonuclear leucocytes and monocytes ${ }^{27}$ in such patients will compromise clearance of bacteria. Malnutrition and alcoholism which often coexist in these patients are also known to impair host defence mechanisms. Although normal peritoneal fluid has antimicrobial activity for a number of organisms, ascitic fluid from cirrhotics has been shown to have impaired, or deficient antimicrobial, or opsonic activity for $E$ coli, streptococcus faecalis and pneumococci. ${ }^{28-30}$ Interestingly, in those studies ascitic fluid was bacteriostatic for bacteroides, which may explain the uncommon isolation of these organisms.

\section{Relationship to invasive procedures}

Invasive procedures such as fibreoptic endoscopy, sigmoidoscopy, balloon tamponade, or paracentesis are potential vehicles of infection. ${ }^{31-35}$ In most series, however, no direct relation between SBP and such procedures has been found. ${ }^{5636}$ Experimental studies have shown, however, that gastrointestinal haemorrhage and acute hypovolaemia may increase intestinal permeability to enteric bacteria and impair hepatic RE function. ${ }^{37}{ }^{38}$ Indeed, it has recently been reported that the incidence of SBP is particularly high immediately after gastrointestinal bleeding and that prophylactic administration of non-absorbable antibiotics is effective in prevention. ${ }^{39}$ Arteriography, especially when accompanied by injection of Vasopressin, has been implicated as a precipitant of SBP, ${ }^{40}$ particularly involving anaerobic organisms. The accompanying vascular spasm and hypoxia may impair gastrointestinal mucosal nutrition and favour transmural spread of bacteria. ${ }^{41-43}$

\section{Clinical and laboratory diagnosis}

Although fever, abdominal pain or tenderness do occur in most patients, symptoms are often minimal and easily overlooked. ${ }^{5-7} 364445$ Nausea, vomiting, or diarrhoea are common. In one third or more of patients there are no symptoms, or signs directly referable to the abdomen. ${ }^{57}$ 
Indirect features pointing to the presence of peritonitis comprise deterioration in hepatic or renal function. Increasing encephalopathy or ascites are particularly common. Such features could readily be attributed to spontaneous progression of liver disease, hence a high index of suspicion is needed. A recent study ${ }^{6}$ has confirmed our experience that a rising creatinine, or temporary resistance to diuretics is often an early sign in such patients.

Diagnostic aspiration of $20 \mathrm{ml}$ ascitic fluid is thus required in a patient with any of these features. In view of the high mortality $(48-70 \%), 67936$ early diagnosis and treatment are imperative, but as the results of bacterial culture are not available for 24-48 hours reliance has to be placed on other characteristics of ascitic fluid infection. Cloudy fluid is present in more than three quarters of patients with SBP and in one third of those with sterile ascites. ${ }^{1036}$ Protein, lactic dehydrogenase concentration and glucose content, although of value in the diagnosis of infection within the pleural space, joint cavity or cerebro-spinal fluid (csf), are not very helpful in the diagnosis of bacterial peritonitis. ${ }^{104647}$ Normal values for protein fall within a range of $0.1-9.6 \mathrm{~g} / \mathrm{l}$ (mean $2 \cdot 0 \pm 0 \cdot 1$ ) compared to $0.5-4.7 \mathrm{~g} / 1$ (mean $1 \cdot 6 \pm 0 \cdot 1$ ) in SBP. The range of glucose concentrations is similarly wide and only $8 \%$ of patients with SBP have a low ascitic fluid glucose with respect to blood. ${ }^{10} \mathrm{~A}$ gram stain of a centrifuged deposit of ascitic fluid should be examined, although organisms are only detected in one third of cases in which SBP is subsequently proven by bacterial culture..$^{5636}$

The commonest way in which diagnosis is established, or even considered is by measurement of the ascitic fluid white cell count. Sterile ascites normally contains less than $300 \mathrm{WBC} / \mathrm{mm}^{3}$, most of which are lymphocytes and less than $25 \%$ polymorphs. Thus a diagnosis of SBP was considered probable when these values were exceeded, ${ }^{5} 10$ although others have suggested that this cut off point is too low, because such numbers of white blood cells can be found in up to $50 \%$ of patients with sterile ascites. ${ }^{44} 48$ Administration of diurectics, however, has now been shown to increase the ascitic fluid white cell count. ${ }^{49}$ As the volume of ascites decreases, protein concentration and numbers of lymphocytes (which have a long life cycle) increase, while polymorphonuclear cells (which have a short lifespan) decrease in the absence of infection. This important observation suggests that the total WBC count should no longer be used as the criterion for the diagnosis of SBP. Instead the diagnosis must be based on the number of polymorphonuclear cells $>250$ / $\mathrm{mm}^{3}$, if there is any suspicion of infection. ${ }^{50}$

Before this observation the lack of specificity of the ascitic white blood cell count as an accurate marker of infection prompted investigation of other means of diagnosis. Much interest followed reports that the $\mathrm{pH}$ of cerebrospinal fluid, pleural and joint fluid produced good discrimination between sterile and infected exudates. ${ }^{51-53}$ Gitlin subsequently reported that an ascitic fluid $\mathrm{pH}$ of 7.31 accurately identified all five of 56 patients with SBP. ${ }^{54}$ Several short reports ${ }^{85-57}$ together with the paper by Scemama-Clerque and colleagues ${ }^{58}$ in this issue have not confirmed this intial experience. In Kao and Reynolds ${ }^{55}$ study none of their five patients with SBP had a pH below 7.31. Similarly Martin and Galambos ${ }^{56}$ studying 45 ascitic fluid specimens found that although ascitic fluid $\mathrm{pH}$ of patients 
with SBP. was lower than the sterile group ( $\mathrm{pH} 7 \cdot 31 \pm 0 \cdot 13$ vs $7 \cdot 39 \pm 0 \cdot 11$ $\mathrm{p}<0.05$ ), the data were so widely scattered that $\mathrm{pH}$ could not reliably identify patients with SBP. Garcia-Tsao and $\mathrm{Conn}^{57}$ found measurement of $\mathrm{pH}$ to be far less sensitive than the ascitic cell count, although it did add to the specificity. Stassen et $a l^{59}$ in a study of only five patients with SBP found little difference between the tests. As might be expected, similar results are to be found by measurement of the ascitic fluid lactate levels. 56575960 The weight of evidence therefore, suggests that an ascitic fluid polymorphonuclear cell count of $>250 / \mathrm{mm}^{3}$ remains the best index for the diagnosis of SBP before the results of bacterial culture are available.

\section{How can survival be improved}

The high prevalence of SBP dictates that ascites should be treated promptly. Further prospective studies need to be undertaken to determine the importance of predisposing factors and the risk of infection with invasive procedures. Prophylaxis with antibiotics may be appropriate in certain patients. The value of gut sterilisation to prevent SBP in patients with upper gastrointestinal bleeding, a proposed high risk group, ${ }^{39}$ merits further study. As host defence mechanisms are impaired intercurrent infections should be treated energetically. Continued awareness of the syndrome, examination of ascitic fluid at the first sign of clinical deterioration and immediate intravenous antibiotics if infection is confirmed, are vital. Early effective antibiotic therapy is an important correlate of survival and rational use of antibiotics is imperative. A cephalosporin, or ampicillin plus an aminoglycoside and metronidazole have been suggested as an appropriate antibiotic regimen for patients with SBP, ${ }^{61}$ as nearly $90 \%$ of isolated organisms would be susceptible in vitro to these agents. The efficacy in vitro may be much lower, ${ }^{61} 62$ however, and Felisant and his colleagues ${ }^{62}$ have shown in a randomised controlled study that cefotaxine is more effective than a combination of ampicillin and tobramycin in cirrhotic patients with severe infections, despite similar in vitro antibacterial activity. This difference in efficacy may be a function of the wide therapeutic/toxic ratio of the cephalosporins, such that high dosages with resultant maximal tissue levels can be achieved without adverse effects. ${ }^{63}$ In contrast, aminoglycosides have a narrow therapeutic band above which nephrotoxicity occurs. Within this range antibiotic concentrations may be close to the minimum inhibitory concentration of the infecting organisms. ${ }^{65} 66$ Indeed it has been suggested that this fact may be of critical importance in patients with impaired host defence mechanisms. ${ }^{67}$ Also in favour of the use of a cephalosporin rather than an aminoglycoside in cirrhotic patients is the suggestion that such patients are predisposed to develop aminoglycoside nephrotoxicity, ${ }^{61} 68$ which may be responsible for a number of late deaths. ${ }^{6}$

Nutritional support is a further area of potential importance. The high incidence of immuno-incompetence may underlie the frequent occurrence of spontaneous infections. The close association of malnutrition and anergy, ${ }^{69}$ so common in patients with decompensated chronic liver disease, suggests a potentially reversible component to this abnormality. 
Where malnutrition alone is the cause of anergy, refeeding can restore immune competence, ${ }^{70}$ and it is possible that host defences in patients with cirrhosis might be improved by more attention to nutritional therapy. Nevertheless, the severity of the underlying liver disease remains the most important determinant of survival.

King's College Hospital and School

I R CROSSLEY AND ROGER WILLIAMS

of Medicine and Dentistry,

Denmark Hill, London

\section{References}

1 Caroli J, Platteborse R. Septicaemie porto-cave, cirrhoses du foie et septicemie a coli bacille. Sem Hôp (Paris) 1958; 34: 472-87.

2 Kerr DNS, Pearson DT, Read AE. Infection of the ascitic fluid in patients with cirrhosis. Gut 1963; 4: 394-8.

3 Conn HO. Spontaneous peritonitis and bacteraemia in Laennec's cirrhosis caused by enteric organisms. A relatively common but rarely recognised syndrome. Ann Intern Med 1984; 60: 568-80.

4 Conn HO, Fessel JM. Spontaneous bacterial peritonitis in cirrhosis. Variations on a theme. Medicine (Balt) 1971; 50: 161-97.

5 Correia JP, Conn HO. Spontaneous Bacterial peritonitis in cirrhosis. Med Clin N Am 1975; 59: 963-81.

6 Hoefs JC, Canawati HN, Sapico FL, Hopkins RR, Weiner J, Montgomerie JZ. Spontaneous bacterial peritonitis. Hepatology 1982; 2: 399-407.

7 Pinzello G, Simonetti RG, Craxi A, Di Piazza S, Spano C, Pagliaro L. Spontaneous bacterial peritonitis. A prospective investigation in predominantly non alcoholic cirrhotic patients. Hepatology 1983; 3: 545-9.

8 Clergue J, Metreau JM, Teisserie B, Dhumeaux D. Ascitic fluid $\mathrm{pH}$ in spontaneous bacterial peritonitis. [Correspondence] Hepatology 1983; 3: 774-5.

9 Curry N, McCallum RW, Guth PH. Spontaneous peritonitis in cirrhotic ascites. A decade of experience. Am J Dig Dis 1974; 19: 685-92.

10 Bar-Meir S, Lerner E, Conn HO. Analysis of ascitic fluid in cirrhosis. Dig Dis Sci 1979; 24: $136-44$.

11 Targan SR, Chow AW, Guze LB. Role of anaerobic bacteria in spontaneous peritonitis of cirrhosis. Report of two cases and review of the literature. Am J Med 1977; 62: 397-403.

12 Martini GA, Phear EA, Ruebner B, Sherlock S. The bacterial content of the small intestine in normal and cirrhotic subjects; relation to methionine toxicity. Clin Sci 1957; 16: $35-51$.

13 Schweinberg FB, Seligman AM, Fine J. Transmural migration of intestinal bacteria. $N$ Engl J Med 1950; 242: 747-50.

14 Gorbach SL. Intestinal microflora. Gastroenterology 1971; 60: 1110-29.

15 Teres J, Rimola A, Sanchez Tapias JM, Planas R, Rhodes J. Spontaneous bacterial peritonitis in cirrhosis of the liver with ascites. In: Gauthier A, ed. Intensive care in hepatology and gastroenterology. Paris: Masson, 1983: 48-56.

16 Beeson PB, Branon ES, Warren JV. Observations of the sites of removal of bacteria from the blood in patients with bacterial endocarditis. J Exp Med 1945; 81: 91-3.

17 Rutenberg AM, Sonnenblick E, Koven I, Schweinberg F, Fine J. Comparative response of normal and cirrhotic rates to intravenously injected bacteria. Proc Soc Exp Biol Med 1959; 101: 279-81.

18 Goresky CA, Huef PM, Villeneuve JP. Blood-tissue exchange and blood flow in the liver. In: Zakin D, Boyer TD, eds. Hepatology. A textbook of liver disease. Eastbourne: W B Saunders, 1982: 32-63.

19 Rimola A, Soto R, Borly F, Arroyo V, Piera C, Rodes J. Reticulo-endothelial system phagocytic activity in cirrhosis and its relation to bacterial infections and prognosis. Hepatology 1984; 4: 53-8. 
20 Denker H, Krammer C, Norryd C, March PA, Tylen U. Examination for aerobic and anaerobic bacteria in human portal blood collected by transumbilical catheterization. Scand J Gastroenterol 1974; 9: 367-9.

21 Triger DR, Boyer TD, Levin J. Portal and systemic bacteraemia and endotoxaemia in liver disease. Gut 1978; 19: 935-9.

22 Fierer J, Finley F. Deficient serum bactericidal activity against E Coli in patients with cirrhosis of the liver. J Clin Invest 1979; 63: 912-21.

23 Wyke RJ, Rajkovic IA, Eddleston ALWF, Williams R. Defective opsonisation in patients with chronic liver disease. [Abstract] Gut 1979; 20: A931.

24 De Meo AN, Anderson BR. Defective chemotaxis associated with a serum inhibitor in cirrhotic patients. $N$ Engl J Med 1972; 286: 735-40.

25 Yousif-Kaduru AGM, Rajkovic IA, Wyke RJ, Williams R. Defects in serum attractant activity in different types of chronic liver disease. Gut 1984; 25: 79-84.

26 Matsuda M, Yamanaka T, Matsuda A. Distribution of fibronectin in plasma and liver disease. Clin Chim Acta 1982; 118: 191-9.

27 Hassner A, Kletter Y, Schlag D, Yedvab M, Aronson M, Shibolet S. Impaired monocyte function in cirrhosis. $\mathrm{Br}$ Med $J$ 1981; 282: 1262-3.

28 Bercovici MJ, Miller J, Sacks TG. Antimicrobial activity of human peritoneal fluid. Surg Gynaecol 1975; 141: 885-7.

29 Fromkes JJ, Thomas FB, Mekhjian HS, Evans M. Antimicrobial activity of human ascitic fluid. Gastroenterology 1977; 73: 668-72.

30 Simberkoff MS, Moldover NH, Weiss G. Bactericidal opsonic activity of cirrhotic ascites and non-ascitic peritoneal fluid. J Lab Clin Med 1978; 91: 831-9.

31 Le Frock JL, Ellis CA, Turchik JB, Weinstein L. Transient bacteraemia associated with sigmoidoscopy. N Engl J Med 1973; 289: 467-9.

32 Small JH Jnr. Bacteraemia with upper gastrointestinal endoscopy. Ann Intern Med 1975; 83: $212-4$.

33 Conn HO. Bacterial peritonitis: spontaneous or paracentetic. Gastroenterology 1979; 77: 1145-6.

34 Bennet JV, Brachman PS. Hospital infections. Boston: Little Brown, 1979.

35 Shorvon PJ, Eykyn SJ, Cotton PB. Gastrointestinal instrumentation, bacteraemia and endocarditis. Gut 1983; 24: 1078-93.

36 Weinstein MP, Iannini PB, Stratton CW, Eickhoff TC. Spontaneous bacterial peritonitis. A review of 28 cases with emphasis on improved survival and factors influencing prognosis. Am J Med 1978; 64: 593-8.

37 Rhodes RS, Depalma RG, Robinson AV. Intestinal barrier function in hemorrhagic shock, J Surg Res 1973; 14: 305-12.

38 Pardy BJ, Spencer RC, Dudley HAF. Hepatic reticuloendothelial protection against bacteraemia in experimental hemorrhagic shock. Surgery 1971; 81: 193-7.

39 Planas R, Rimola A, Sanches-Tapias JM, Teres J, Bruguera M, Rhodes J. Antibiotieos orates no absorbibles en el tratamiento de la peritontits bacteriama espontanea de la cirrhosis hepatica. Gastroenterol Hepatol 1981; 4: 499-503.

40 Bar-Meir S, Conn HO. Spontaneous bacterial peritonitis induced by intra arterial vasopressin. Gastroenterology 1976; 70: 418-21.

41 Davis GB, Bookstein J, Hagan PL. The relative effects of selective intra arterial and intravenous vasopressin infusion. Radiology 1976; 120: 537-8.

42 Mallory A, Schaefer JW, Cohen JR, Holt SA, Norton LW. Selective intra arterial vasopressin infusion for upper gastrointestinal tract haemorrhage. Arch Surg 1980; 115: 30-32.

43 Conn HO, Ramsby SR, Storer EN. Selective intra arterial vasopressin in the treatment of upper gastrointestinal haemorrhage. Gastroenterology 1972; 63: 634-45.

44 Kline MM, McCallum RW, Guth PH. The clinical value of ascitic fluid culture and leukocyte count studies in alcoholic cirrhosis. Gastroenterology 1976; 70: 408-12.

45 Macrae FA, St John DJB. Spontaneous bacterial peritonitis reversible cause of deterioration in patients with cirrhosis. Med J Aust 1980; 2: 209-11.

46 Boyer TD, Kahn AM, Reynolds TB. Diagnostic value of ascitic fluid lactic dehydrogenase, protein and WBC levels. Arch Intern Med 1978; 138: 1103-5.

47 Sampliner RE, Iber FL. High protein with uncomplicated hepatic cirrhosis. Ann J Med Sci 1974; 267: 275-9.

48 Wilson JA, Suguiltan EA, Cassidy WA, Parker RH, Chan CH. Characteristic of ascitic fluid in the alcoholic cirrhotic. Dig Dis Sci 1979; 24: 645-8.

49 Hoefs JS. Increase in ascites white blood cell and protein concentration during diuresis in 
patients with chronic liver disease. Hepatology 1981; 1: 249-54.

50 Conn HO. Making sense out of nonsense. Hepatology 1981; 1: 370-2.

51 Bland RD, Lister RC, Ries JP. Cerebrospinal fluid lactic acid level and $\mathrm{pH}$ in meningitis. Aids in differential diagnosis. Am J Dis Child 1974; 128: 151-6.

52 Good JT, Taryle DA, Maulitz RM et al. The diagnostic value of pleural fluid pH. Chest 1980; 78: 55-9.

53 Trehalt PS, McCerty DJ. Synovial fluid $\mathrm{pH}$, lactate, oxygen and carbon dioxide partial pressure in various joint diseases. Arthr Rheum 1971; 14: 475-84.

54 Gitlin N, Stauffer JL, Silvestri R. The $\mathrm{pH}$ of ascitic fluid in the diagnosis of spontaneous bacterial peritonitis in alcoholic cirrhosis. Hepatology 1982; 2: 408-11.

$55 \mathrm{Kao} \mathrm{HW}$, Reynolds TB. Ascitic $\mathrm{pH}$ and spontaneous bacterial peritonitis. [Correspondence] Hepatology 1983; 3: 275.

56 Martin DM, Galambos JT. Ascitic fluid $\mathrm{PO}_{2}$ in spontaneous bacterial peritonitis. [Abstract] Gastroenterology 1984; 86: 1130.

57 Garcia-Tsao G, Conn HO. Ascitic fluid and blood $\mathrm{pH}$ and lactate levels in the diagnosis of bacterial peritonitis. [Abstract] Hepatology 1983; 3: 851.

58 Scemama-Clergue J, Doutrellot Rhilippon C, Metreau J-M, Teisseire B, Capron D, Dhumeaux D. Ascitic fluid $\mathrm{pH}$ in alcoholic cirrhosis: a re-evaluation of its utility in the diagnosis of spontaneous bacterial peritonitis. Gut 1985; 26: 332-5.

59 Stassen W, Bacon BR, McCullough AJ, Gufnik S, Kalhan S, Tavill AS. Superior diagnostic value of ascitic fluid $\mathrm{pH}$ and lactate levels as immediate indicators of infected ascites. [Abstract] Gastroenterology 1984; 86: 1341.

60 Brook I, Altman RS, Loebman WW, Seeff LB. Measurement of lactate in ascitic fluid. An aid in the diagnosis of peritonitis with particular reference to spontaneous bacterial peritonitis of the cirrhotic. Dig Dis Sci 1981; 26: 1089-95.

61 Cabrera J, Arroyo V, Ballesta AM. Aminoglycoside nephrotoxicity in cirrhosis. Value of urinary $B_{2}$ microglobulin to discriminate functional renal failure from acute tubular damage. Gastroenterology 1982; 82: 97-105.

62 Felisant J, Rimola A, Arroyo V, Rodes J. Estudio comparativo de la eficaein teraoeutid y nefrotoxicidad de ampicilina mes tobramicina versus cefotaxime. [Abstract] Gastroenterol Hepatol 1984; 7: 272.

63 Morean L, Durand H, Biclet P. Cefotaxime concentration in ascites. J Antimicrob Chemer 1980; 6: 121-2.

64 Carmine A, Brogden RN, Heel et al. Cefotaxime. A review of its antibacterial activity, pharmacologic properties and therapeutic use. Drugs 1983; 25: 223-89.

65 Gerding DN, Hall WH, Schierl EA. Antibiotic concentrations in ascitic fluid of patients with ascites and bacterial peritonitis. Ann Intern Med 1977; 86: 708-13.

66 Escargarza E, Hill J, Gonzalez et al. Laboratory and clinical evaluation of tobramycin a new aminoglycoside antibiotic. $J$ Infect Dis 1976; suppl: 5158-64.

67 Bodey GP, Ketchel SJ, Rodriguez V. A randomised study of carbenicillin plus cefamandole or tobramycin in the treatment of febrile episodes in cancer patients. Am J Med 1979; 67: 608-16.

68 Moore RD, Smith CR, Lipsky JJ, Mellits ED, Lietau PS. Risk factors for nephrotoxicity in patients treated with amino glycosides. Ann Intern Med 1984; 100: 352-7.

69 O'Keefe SJ, El-Zayadi AR, Carraher TE, Davis M, Williams R. Malnutrition and immunoincompetance in patients with liver disease. Lancet 1980; 2: 615-7.

70 Spanier AH, Pietsch JB, Meakin JL et al. The relationship between immune competance and nutrition. Surg Forum 1976; 27: 332-5. 